\title{
Ocena skuteczności oczyszczania kolumny rur okładzinowych przed cementowaniem na podstawie badań przy użyciu wiskozymetru obrotowego
}

\begin{abstract}
Zapewnienie odpowiedniej szczelności otworu wiertniczego i wyeliminowanie niekontrolowanych przepływów gazu polega w głównej mierze na uszczelnieniu kolumny rur okładzinowych poprzez wypełnienie przestrzeni pierścieniowej bądź pozarurowej zaczynem cementowym. Takie działanie dodatkowo stabilizuje kolumnę rur poprzez zespolenie jej w dolnej części ze ścianą otworu, a w górnej części z poprzednią kolumną rur o większej średnicy $[6,10,11]$. Tłoczony przez przestrzeń pierścieniową zaczyn cementowy wypiera płuczkę, jednakże nie jest on w stanie dostatecznie dobrze usunąć pozostałości po niej. Warunkiem dobrego uszczelnienia zaczynem cementowym, który po związaniu ma uniemożliwić przepływ gazu, jest wcześniejsze dokładne oczyszczenie przestrzeni pierścieniowej z osadu płuczkowego poprzez przetłoczenie cieczy przemywającej. Usunięcie osadu płuczkowego zarówno z powierzchni formacji skalnej, jak i rur okładzinowych wpływa na poprawę uszczelnienia oraz umożliwia wyeliminowanie niepożądanego zjawiska migracji gazu na kontakcie płaszcza cementowego z rurą okładzinową oraz formacją skalną [2, 4, 21, 24]. Problem poprawy szczelności otworów wiertniczych przyczynił się do poszerzenia kierunku badań nad odpowiednim przygotowaniem przestrzeni pierścieniowej przed cementowaniem. W tym celu prowadzone są badania nad usunięciem osadu płuczkowego, zarówno z formacji skalnej, jak i z powierzchni rur okładzinowych. Odpowiednio dobrana ciecz przemywająca powinna wykazywać skuteczność pod względem usuwania osadu z powierzchni skały oraz z powierzchni rury. Jednak w celu osiągnięcia wymaganych rezultatów każdą powierzchnię (rury okładzinowe, formacja skalna) należy rozpatrywać indywidualnie $[5,8,9]$. Dlatego też w niniejszej publikacji omówiona została metodyka badań usuwania osadu poprzez wykorzystanie wiskozymetru obrotowego oraz skuteczność usuwania osadu płuczkowego z powierzchni kolumny rur okładzinowych. Przeprowadzenie badań przy użyciu wiskozymetru obrotowego podyktowane było tym, że niemal każde laboratorium zaczynów cementowych posiada na wyposażeniu tego rodzaju urządzenie. W trakcie badań wykonano testy dla różnych środków, których dobór, zarówno ilościowy, jak i jakościowy, umożliwiał poprawienie efektywności usuwania osadu płuczkowego. Badania skuteczności usuwania osadu prowadzone były na podstawie porównania uzyskanych wyników w stosunku do próbki wzorcowej, którą było usunięcie osadu przy użyciu wody. Analiza uzyskanych wyników badań umożliwiła wytypowanie cieczy o najlepszej efektywności oczyszczania powierzchni kolumny rur okładzinowych z wytworzonego osadu płuczkowego.
\end{abstract}

Słowa kluczowe: ciecz przemywająca, przemywka, oczyszczenie przestrzeni pierścieniowej, kolumna rur okładzinowych, osad płuczkowy, cementowanie otworu wiertniczego, środki powierzchniowo czynne, surfaktanty, przestrzeń pierścieniowa, wiskozymetr obrotowy.

\section{Cleaning of the casing string before cementation, based on research using a rotational viscometer}

Ensuring proper sealing-off of the borehole and elimination of uncontrolled flows of gas, mainly consists in sealing the casing string by filling the annular space with cement slurry. Such action additionally stabilizes the casing string by binding it in the lower part of the casings with the borehole wall, and in the upper part with the previous casings of larger diameter. During the pumping of cement slurry, drilling mud is removed form annular space, but it is not always possible to sufficiently remove residues from the mud. In order to properly seal the borehole with cement slurry, which after binding is designed to prevent the flow of gas, it is necessary to thoroughly clean the annular space from mud cake by pumping the preflush fluid. The removal of the filter cake from the rock formation and casing string improves the sealing and eliminates the possibility of undesirable gas migration at the contact of the cement sheath with the casing string and rock formation. The problem of improving the sealing of boreholes has contributed to extend the research on the appropriate preparation of the annular space before ce- 
mentation. For this purpose, laboratory tests have been carried out on the removal of mud cake from the rock formation and the surface of the casing string. Properly selected preflush fluid should be effective in removing filter cake from the surface of the rock and from the surface of the casing. However, in order to achieve the required results, each surface (casing string, rock formation) should be considered individually. Therefore, this paper discusses the methodology of mud cake removal by using a rotational viscometer and efficiency of removing the mud cake from the surface of the casing string. Conducting the research using a rotational viscometer was dictated by the fact, that almost every cement slurry laboratory, has this type of equipment. During the research, tests were carried out for various agents, the selection of which, both quantitatively and qualitatively enabled the improvement of the removal efficiency of the mud cake. The filter cake removal effectiveness tests were based on a comparison of the obtained results with the reference sample, which was the removal of the mud cake using water. Based on the analysis of the obtained results, the wash fluids with the best efficiency of cleaning the surface of casing string from the mud cake was selected.

Key words: preflush fluid, wash fluid, cleaning of the annular space, casing string, mud cake, well cementing, surfactants, annular space, rotational viscometer.

\section{Wprowadzenie}

Mając na uwadze istotę problemu braku szczelności odwiertów, od kilku lat zwraca się szczególną uwagę na zabieg cementowania jako na jedną z ważniejszych operacji w trakcie realizacji otworu. W związku z tym w Instytucie Nafty i Gazu - Państwowym Instytucie Badawczym prowadzi się specjalistyczne badania w celu poprawy oczyszczenia przestrzeni pierścieniowej otworu.

Przed zabiegiem cementowania do przestrzeni pierścieniowej zatłaczana jest sekwencja płynów w celu wyparcia płuczki wiertniczej i przygotowania przestrzeni pierścieniowej bądź pozarurowej do wypełnienia jej zaczynem cementowym [20]. Stosowana podczas wiercenia płuczka posiada parametry, które zostały zaprojektowane do określonych warunków otworowych, jednakże parametry te mogą mieć niekorzystny wpływ na usuwanie powstałego z niej osadu płuczkowego podczas wytłaczania płuczki z otworu $[22,36]$. W związku z powyższym wymagane jest odpowiednie przygotowanie płuczki, tzn. zmodyfikowanie jej właściwości. Zmiana parametrów reologicznych płuczki po zapuszczeniu kolumny rur okładzinowych określana jest mianem obróbki płuczki, po której to czynności do otworu wtłacza się ciecze wyprzedzające (przemywającą i buforową) $[19,23,25]$. Ciecze te pozwalają na przygotowanie przestrzeni pierścieniowej do zabiegu cementowania. Wymagania, jakie narzuca się cieczom wyprzedzającym, to [16-18, 20]:

- konieczność pozostawienia nawilżonej kolumny rur okładzinowych oraz formacji skalnej w celu poprawy wiązania zaczynu cementowego;

- konieczność wtłaczania cieczy przy zachowaniu przepływu turbulentnego w celu poprawy skuteczności usuwania płuczki;

- wyeliminowanie możliwości powodowania powstawania szczelin w formacji, co może się zdarzyć, jeżeli wydatek tłoczenia ulegnie nadmiernemu wzrostowi;

- zapewnienie wystarczającego czasu kontaktu cieczy wyprzedzających w przestrzeni pierścieniowej lub pozaruro- wej w celu uzyskania optymalnego stopnia usunięcia płuczki i odpowiedniego oczyszczenia rur okładzinowych i formacji skalnej z osadu płuczkowego;

- możliwie łatwe usunięcie cieczy wyprzedzającej z przestrzeni pierścieniowej przez wtłaczany zaczyn cementowy. Wpływ zastosowanej cieczy wyprzedzającej jest proporcjonalny do czasu kontaktu tej cieczy ze ścianą otworu w przestrzeni pierścieniowej. Ciecze wyprzedzające można podzielić na ciecze przemywające, czyli przemywki (nieobciążone płyny), oraz ciecze buforowe, którymi są obciążone płyny (bufory) (rysunek 1). Przemywki posiadają właściwości reologiczne cieczy newtonowskich i powodują dyspergowanie płuczki. Ze względu na ich niską lepkość są szczególnie przydatne podczas wtłaczania w przepływie turbulentnym. Ciecze przemywające stosowane są do oczyszczenia przestrzeni pierścieniowej z pozostałości osadu płuczkowego. Umożliwiają one również poprawę przyczepności wiążącego zaczynu cementowego z kolumną rur okładzinowych oraz z formacją skalną [13-15, 17]. Parametry technologiczne cieczy przemywających powinny być bardzo precyzyjnie zaprojektowane. W celu lepszego zdyspergowania płuczki stosuje się chemiczne przemywki, które stanowią mieszaninę rozpuszczalników i środków powierzchniowo czynnych [13, 17, 18$]$.

Jedną z zalet stosowania przemywających cieczy wyprzedzających jest ich wysoki potencjał usuwania osadu płuczkowego podczas tłoczenia ich w przepływie turbulentnym. Zachodzi jednakże ryzyko naruszenia stateczności ściany otworu lub/i dopływu płynów złożowych podczas zatrzymania krążenia, ze względu na niską gęstość przemywek. Dlatego też harmonogram tłoczenia wyprzedzających cieczy przemywających powinien być tak zaprojektowany, aby ciśnienie hydrostatyczne w przestrzeni pierścieniowej nie spadło poniżej ciśnienia złożowego. W celu utrzymania ciśnienia hydrostatycznego cieczy przemywającej na wymaganym poziomie istnieje możliwość dodatkowego obciążenia wyprzedzającej cieczy 


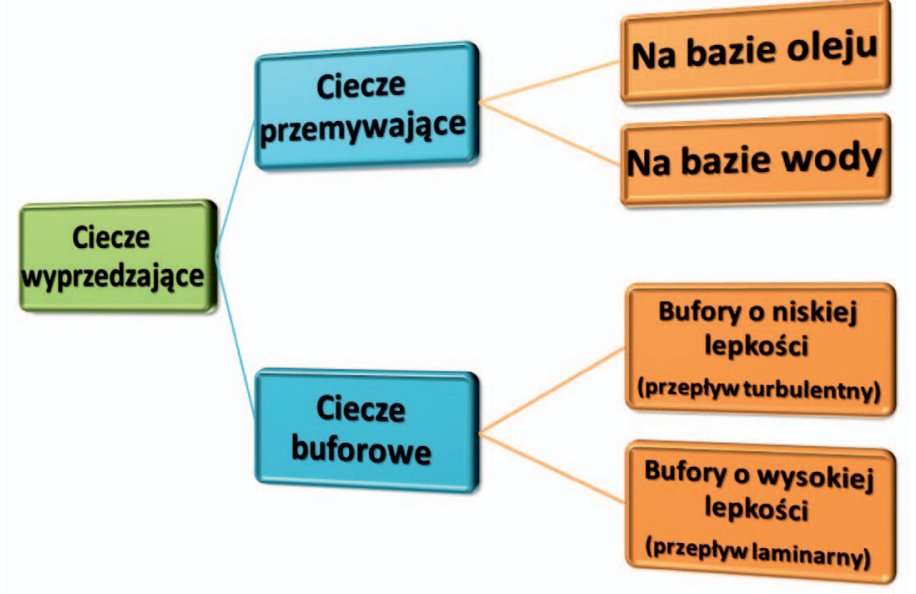

Rys. 1. Klasyfikacja cieczy wyprzedzających

przemywającej, co nadaje jej charakter cieczy buforowej. Jednakże często się zdarza, że dodatki obciążające wymagają zastosowania środków zwiększających lepkość danej cieczy. Mieszanina dodatków w tego rodzaju cieczy buforowej powoduje obniżenie przyczepności na kontakcie stwardniały zaczyn cementowy - rura okładzinowa / formacja skalna, dlatego też istotne jest zatłoczenie cieczy przemywającej, a dopiero po niej odpowiednio dobranej obciążonej cieczy buforowej.

O skuteczności usuwania osadu filtracyjnego zarówno z powierzchni rur okładzinowych, jak też z powierzchni skały decyduje szereg parametrów. Są to między innymi: czas kontaktu cieczy przemywającej z kolumną rur okładzinowych czy formacją skalną, wydatek tłoczenia i związana z nim prędkość przepływu cieczy przemywającej w przestrzeni pierścieniowej, skład chemiczny i odpowiednia koncentracja środków powierzchniowo czynnych, surfaktantów bądź innych dodatków w przemywce czy rodzaj powierzchni, z której usuwany jest powstały z płuczki osad filtracyjny $[3,7,12]$. Zupełnie inaczej zachowuje się osad wytworzony na powierzchni rury okładzinowej niż osad na powierzchni formacji skalnej. Między innymi można tutaj wyróżnić czynnik odfiltrowywania cieczy z osadu płuczkowego w formację skalną i brak filtracji cieczy w przypadku powierzchni rur okładzinowych. Nie bez znaczenia jest również chropowatość powierzchni rury okładzinowej. W związku z tym, że podczas projektowania cieczy przemywającej należy dobrać jej parametry pod kątem kompleksowego usuwania osadu z powierzchni o mocno zróżnicowanej charakterystyce, na etapie projektowania należy przeprowadzić badania skuteczności usuwania osadu z każdej powierzchni indywidualnie. Dlatego też w dalszej części artykułu omówiono badania skuteczności usuwania osadu płuczkowego z powierzchni rur okładzinowych.

Podczas realizacji prac przedstawionych $\mathrm{w}$ niniejszej publikacji wykorzystano zarówno ciecze przemywające stosowane dotychczas, jak też nowe środki wpływające na poprawę oczyszczenia przestrzeni pierścieniowej. Wykonano także próby modyfikacji składów cieczy przemywających pod kątem zwiększenia efektywności usuwania osadów filtracyjnych utworzonych przez wykorzystywane płuczki wiertnicze. $\mathrm{Na}$ podstawie kompleksowych badań laboratoryjnych przeprowadzono analizę otrzymanych wyników.

\section{Przebieg prac badawczych}

Badania oczyszczania kolumny rur okładzinowych przed cementowaniem przy użyciu wiskozymetru obrotowego były wykonywane w Laboratorium Zaczynów Uszczelniających INiG - PIB na podstawie norm: PN-85/G-02320 Cementy $i$ zaczyny cementowe do cementowania $w$ otworach wiertniczych; PN-EN 10426-2 Przemyst naftowy i gazowniczy. Cementy i materiaty do cementowania otworów. Część 2: Badania cementów wiertniczych oraz API SPEC 10 Specification for materials and testing for well cements.

Prace badawcze polegały na określeniu efektywności oczyszczania powierzchni rur okładzinowych z wytworzonego osadu płuczkowego. Badania wykonano na podstawie pomiaru stopnia usunięcia osadu płuczkowego z powierzchni rotora wiskozymetru obrotowego (fotografia 1). Badanie tego rodzaju stanowi jeden ze standardowych testów, który pozwala określić efektywność usuwania osadu z płuczki wiertniczej przez ciecze przemywające zarówno przed zabiegiem cementowania, jak i przy doborze cieczy przemywających stosowanych do oczyszczania przestrzeni pierścieniowej lub procesu wymiany płuczki na ciecz nadpakerową. Badanie polega na zanurzeniu rotora (fotografia 2) symulującego powierzchnię rur okładzinowych w płuczce, a następnie tworzeniu na jego powierzchni osadu wskutek obrotu rotora $\mathrm{z}$ określoną prędkością oraz przy określonym czasie kontaktu. Liniowa prędkość przepływu cieczy przemywającej została przeliczona na prędkość obrotową według poniższych zależności:

Związek pomiędzy prędkością liniową a prędkością kątową:

$$
\omega=\frac{v}{R}
$$

gdzie:

$\omega$ - prędkość kątowa [rad/s] (lub opuszczając radiany: $\left.\left[1 / \mathrm{s}=\mathrm{s}^{-1}\right]\right)$,

$v$ - prędkość liniowa, czyli „Zwykła” prędkość punktu [m/s], $R$ - promień okręgu, którego fragmentem jest zakreślany łuk $[\mathrm{m}]$.

$$
v=\omega R
$$




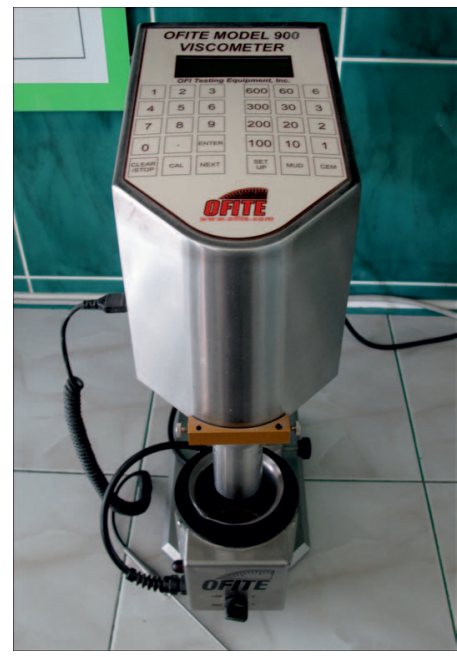

Fot. 1. Wiskozymetr obrotowy Fann model 900

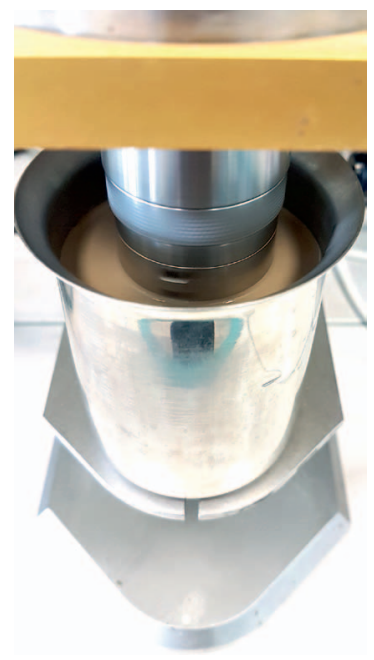

Fot. 2. Rotor zanurzony w płuczce (wytwarzanie osadu płuczkowego)
Podstawiając definicję kąta do wzoru na prędkość liniową, otrzymano:

$$
\omega=\frac{\Delta \alpha}{\Delta t}=\frac{\frac{\Delta L}{R}}{\Delta t}=\frac{\Delta L}{\Delta t} \frac{1}{R}
$$

Następnie uwzględniając, że prędkość liniowa to:

$$
\frac{\Delta L}{\Delta t}=v
$$

otrzymano:

$$
\omega=\frac{v}{R}
$$

Ze względu na to, że powierzchnia rur okładzinowych charakteryzuje się znacznie wyższą chropowatością niż powierzchnia rotora wiskozymetru, poddano go modyfikacji poprzez nałożenie na rotor siatki (fotografia 3 ) o wymiarach oczek $0,05 \times 0,05 \mathrm{~mm}$ oraz grubości drutu $0,035 \mathrm{~mm}$. Modyfikacja taka miała na celu wychwycenie większej ilości osadu z płuczki podczas ruchu obrotowego. Po wytworzeniu osadu (fotografia 4) na zmodyfikowanej powierzchni rotora osad płuczkowy usuwano w cieczy przemywającej (fotografia 5). Pozycje literaturowe [1] podają prędkość obrotową podczas badań na poziomie ok. $100 \mathrm{obr} / \mathrm{min}$, jednakże na podstawie obliczeń określających prędkość przepływu

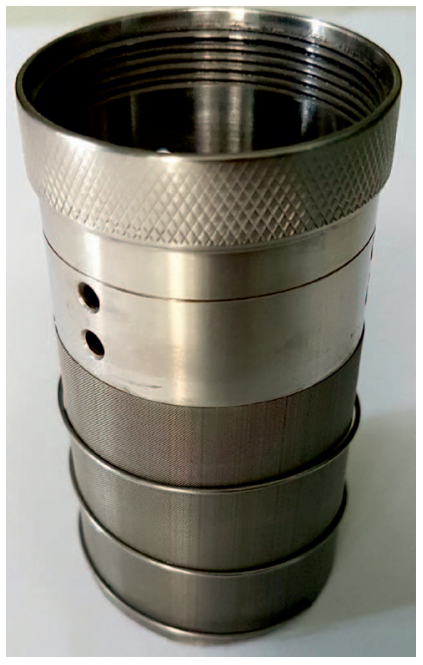

Fot. 3. Widok rotora zmodyfikowanego przy użyciu siatki stalowej

cieczy wiertniczej, a także przeprowadzonych prób wstępnych ustalono prędkość obrotową równą 60 obr/min oraz czas kontaktu cieczy wynoszący 5 min [12].

Podczas analizy oczyszczania kolumny rur okładzinowych na podstawie badania przy zastosowaniu wiskozymetru obrotowego określano masę rotora przed wytworzeniem osadu $\left(m_{0}\right)$. Kolejnym etapem było wytworzenie osadu płuczkowego, po czym ponownie określano masę rotora $\mathrm{z}$ osadem $\left(m_{1}\right)$. Natomiast $\mathrm{w}$ końcowym etapie usuwano osad $\mathrm{z}$ powierzchni rotora, poprzez jego ruch obrotowy w cieczy przemywającej, po czym ponownie ważono rotor z pozostałością osadu płuczkowego po płukaniu $\left(m_{2}\right)$. Na podstawie uzyskanych wyników określono procentową skuteczność usuwania osadu płuczkowego według wzoru:

$$
\%=100 \cdot \frac{m_{1}-m_{2}}{m_{1}-m_{0}}
$$

gdzie:

$\%$ - procent wymycia osadu,

$m_{0}$ - masa rotora przed testem (bez osadu),

$m_{1}$ - masa rotora z osadem płuczkowym,

$m_{2}$ - masa rotora z pozostałością osadu płuczkowego (po przemyciu).

Do wytworzenia osadu płuczkowego zastosowano płuczkę beziłową. Umożliwiała ona wytworzenie warstwy osadu, który przy niewielkiej prędkości obrotowej rotora pozwalał na określenie skuteczności działania danego środka do sporządzania cieczy przemywającej. W celu odzwierciedlenia osadu z przewiercanych formacji skalnych płuczka pochodziła z otworu P26 i zawierała zanieczyszczenia z przewiercanego interwału pod sekcję rur 7". Aby określić efektywność usuwania osadu płuczkowego z powierzchni rur okładzinowych, wy-

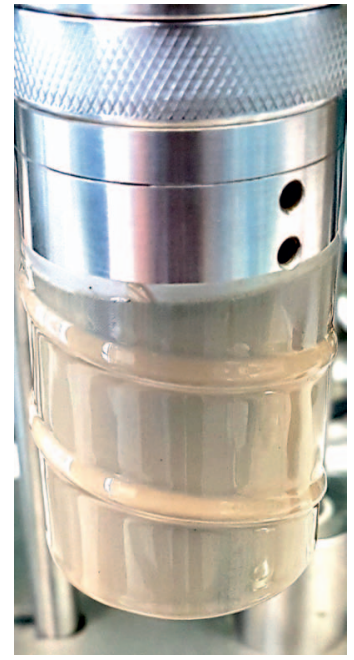

Fot 4. Rotor $\mathrm{z}$ utworzonym osadem pluczkowym

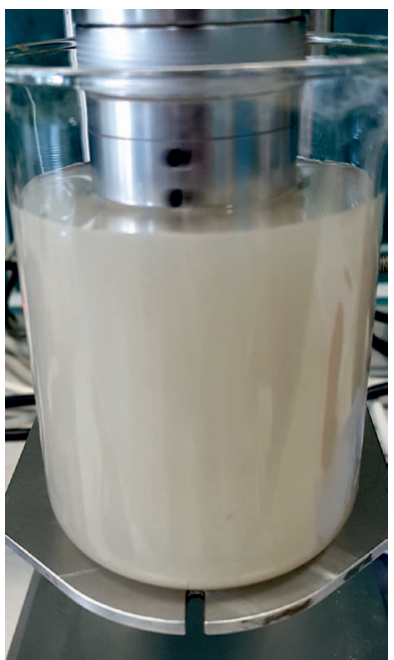

Fot 5. Usuwanie osadu $\mathrm{z}$ powierzchni rotora 
tworzony na powietrzni rotora osad filtracyjny usuwano przy użyciu wytypowanych cieczy przemywających. Punktem odniesienia była procentowa skuteczność usuwania osadu za pomocą wody, natomiast wytypowanymi do badań środkami do sporządzania cieczy przemywających były:

- $\mathrm{MDC}$ - anionowy środek powierzchniowo czynny stosowany do oczyszczania przestrzeni pierścieniowej;

- RL8 - niejonowy związek powierzchniowo czynny;

- $\mathrm{CD}$ - alkilopoliglukozyd alkoholu tłuszczowego $\mathrm{C}_{8}-\mathrm{C}_{10}$;

- RR26 - środek wykorzystywany jako emulgator, dyspergator, solubilizator oraz środek zmiękczający w przemyśle;

- RR21 - kopolimer blokowy tlenku etylenu i tlenku propylenu;

- DN - środek powierzchniowo czynny stosowany do oczyszczania przestrzeni pierścieniowej po płuczce olejowej.

W celu sporządzenia cieczy przemywającej zastosowano koncentrację $0,1 \%$ oraz $1,0 \%$ różnych rodzajów środków przemywających. W tablicy nr 1 zestawiono uzyskane wyniki badań usuwania osadu.

Podczas badań usuwania osadu płuczkowego z powierzchni rotora wiskozymetru obrotowego za pomocą bazowej cieczy przemywającej, którą była woda, uzyskano usunięcie osadu z powierzchni rotora na poziomie 55,4\%. Wartość tę przyjęto jako punkt odniesienia. Następnie w celu usuwania osadu płuczkowego użyto wodnych roztworów różnych cieczy przemywających.
Pierwszą poddaną badaniom cieczą był roztwór środka MDC. Na podstawie uzyskanych wyników badań stwierdzono usunięcie osadu na poziomie $70,87 \%$ podczas użycia roztworu 0,1-procentowego, natomiast wzrost stężenia MDC do $1 \%$ skutkował ponad 75,5-procentowym usunięciem osadu. Drugim środkiem był RL8, którego koncentracja 0,1\% pozwalała na uzyskanie skuteczności usuwania osadu porównywalnej do działania czystej wody, natomiast wzrost koncentracji RL8 do 1\% spowodował znaczną poprawę usunięcia osadu, które wynosiło 74,14\%. Roztwory kolejnego środka, o nazwie $C D$, powodowały usuwanie wytworzonego na powierzchni rotora osadu w zakresie od 67,21\% przy stężeniu $0,1 \%$ do $74,77 \%$ przy zastosowaniu stężenia 1,0\%. Roztwór środka RR26 o koncentracji 0,1\% pozwalał na usunięcie osadu na poziomie ponad $66 \%$, co stanowiło wartość niewiele większą niż oczyszczenie rotora za pomocą wody, natomiast wzrost koncentracji RR26 do wartości 1\% skutkował poprawą oczyszczenia powierzchni rotora i osiągnięciem poziomu 74,44\%. Kolejny środek, o kodowanej nazwie RR21, powodował usunięcie osadu w zakresie od $62,65 \%$ przy najmniejszej koncentracji, wynoszącej 0,1\%, środka, do 75,84\% przy użyciu 1-procentowego środka RR21. Zaznaczyć należy, że była to najwyższa z osiągniętych skuteczności usuwania osadu płuczkowego z powierzchni rotora. Ostatnim z badanych środków był DC, którego zakres skuteczności usuwania osadu wynosił od 71,54\% do 74,66\% (dla wytypowanych

Tablica 1. Wyniki badań efektywności usuwania osadu płuczkowego wytworzonego na powierzchni rotora

\begin{tabular}{|c|c|c|c|c|c|c|c|c|c|c|c|c|}
\hline \multirow{2}{*}{$\begin{array}{c}\text { Lp. } \\
1\end{array}$} & \multirow[t]{2}{*}{ 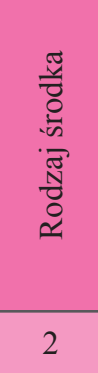 } & \multirow[t]{2}{*}{ 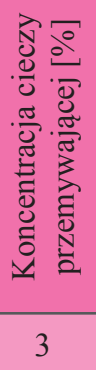 } & \multicolumn{2}{|c|}{ 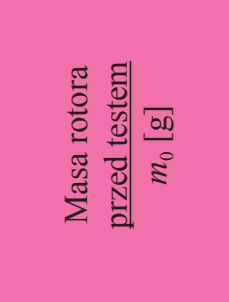 } & \multicolumn{2}{|c|}{ 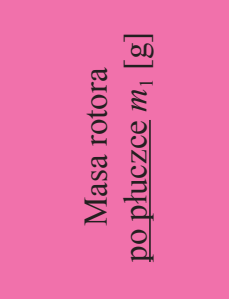 } & \multicolumn{2}{|c|}{ 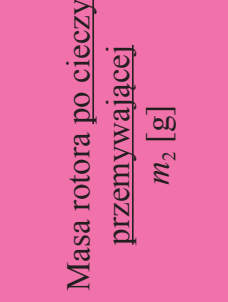 } & \multicolumn{2}{|c|}{ 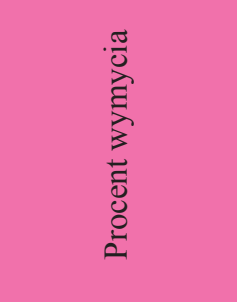 } & \multirow[t]{2}{*}{ 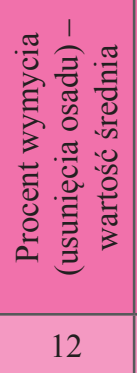 } & \multirow[t]{2}{*}{ 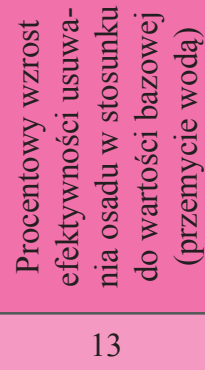 } \\
\hline & & & 4 & 5 & 6 & 7 & 8 & 9 & 10 & 11 & & \\
\hline 2 & woda & - & 72,18 & 72,21 & 74,57 & 74,85 & 73,27 & 73,36 & 54,39 & 56,44 & 55,42 & 0,0 \\
\hline 3 & \multirow{2}{*}{$\mathrm{MDC}$} & $0,1 \%$ & 72,12 & 72,24 & 74,31 & 74,47 & 72,63 & 73,02 & 76,71 & 65,02 & 70,87 & 27,9 \\
\hline 4 & & $1,0 \%$ & 72,25 & 72,32 & 74,42 & 74,27 & 72,80 & 72,78 & 74,65 & 76,41 & 75,53 & 36,3 \\
\hline 5 & \multirow{2}{*}{ RL8 } & $0,1 \%$ & 72,20 & 72,22 & 74,45 & 74,47 & 73,28 & 73,16 & 52,00 & 58,22 & 55,11 & $-0,6$ \\
\hline 6 & & $1,0 \%$ & 72,11 & 72,13 & 74,09 & 74,13 & 72,57 & 72,70 & 76,77 & 71,50 & 74,13 & 33,8 \\
\hline 7 & \multirow{2}{*}{$\mathrm{CD}$} & $0,1 \%$ & 72,36 & 72,38 & 74,18 & 74,25 & 72,95 & 73,00 & 67,58 & 66,84 & 67,21 & 21,3 \\
\hline 8 & & $1,0 \%$ & 72,13 & 72,25 & 74,25 & 74,29 & 72,68 & 72,75 & 74,06 & 75,49 & 74,77 & 34,9 \\
\hline 9 & \multirow{2}{*}{ RR26 } & $0,1 \%$ & 72,18 & 72,22 & 74,44 & 74,34 & 73,15 & 73,00 & 57,08 & 63,21 & 60,14 & 8,5 \\
\hline 10 & & $1,0 \%$ & 72,28 & 72,36 & 74,35 & 74,48 & 72,85 & 72,86 & 72,46 & 76,42 & 74,44 & 34,3 \\
\hline 11 & \multirow{2}{*}{ RR21 } & $0,1 \%$ & 72,25 & 72,28 & 74,51 & 74,65 & 73,08 & 73,18 & 63,27 & 62,03 & 62,65 & 13,0 \\
\hline 12 & & $1,0 \%$ & 72,25 & 72,12 & 74,59 & 74,61 & 72,77 & 72,77 & 77,78 & 73,90 & 75,84 & 36,8 \\
\hline 13 & \multirow{2}{*}{$\mathrm{DN}$} & $0,1 \%$ & 72,13 & 72,02 & 74,59 & 74,37 & 72,85 & 72,67 & 70,73 & 72,34 & 71,54 & 29,1 \\
\hline 14 & & $1,0 \%$ & 72,24 & 72,12 & 74,53 & 74,02 & 72,81 & 72,61 & 75,11 & 74,21 & 74,66 & 34,7 \\
\hline
\end{tabular}




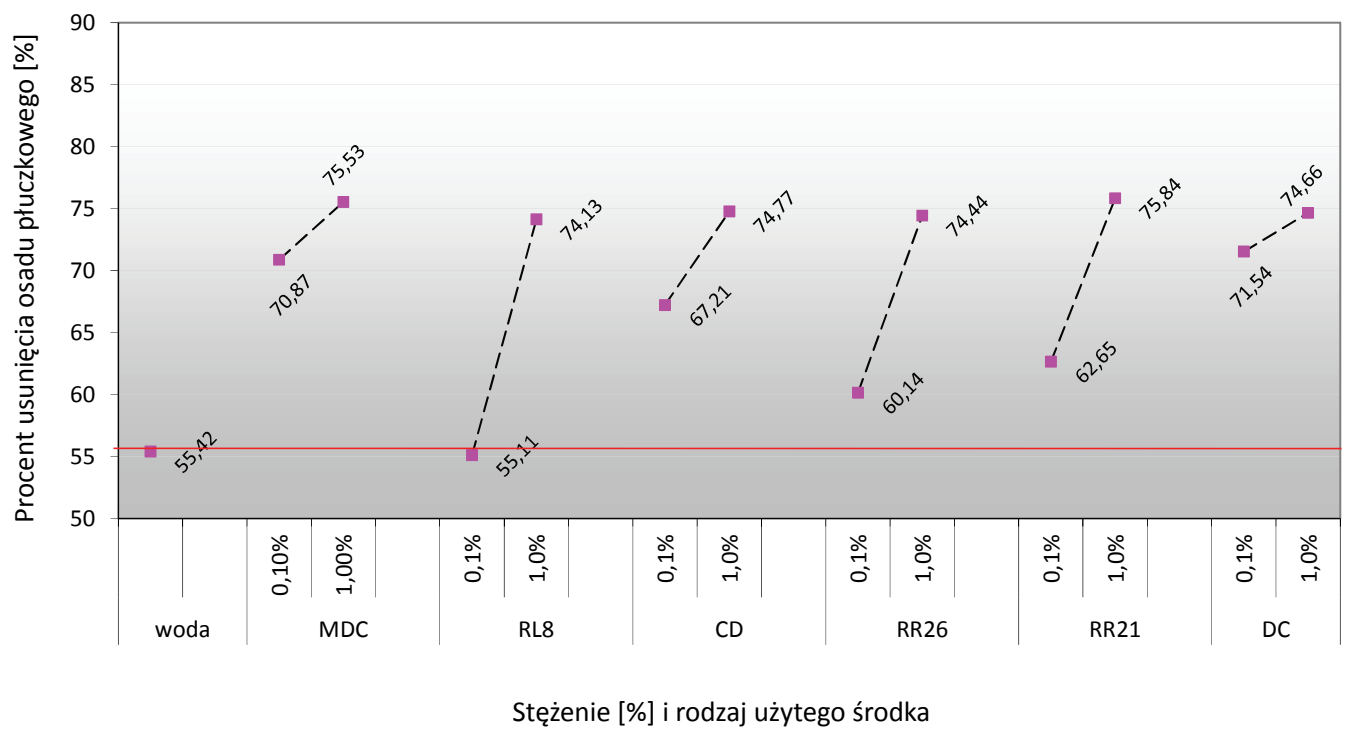

Rys. 2. Zestawienie procentowych wartości usunięcia wytworzonego na powierzchni rotora osadu płuczkowego

koncentracji środka). Zestawienie graficzne uzyskanych wyników skuteczności usuwania osadu płuczkowego z powierzchni rotora przedstawiono na rysunku 2 .

Analizując otrzymane wyniki badań, stwierdzono, że skuteczność usuwania osadu płuczkowego wytworzonego na powierzchni rotora (wyrażana w procencie wymycia/usunięcia) zawierała się w przedziale od $55,11 \%$ do $75,84 \%$. Najniższą wartość, równą $55,11 \%$, uzyskano podczas zastosowania 0,1-procentowego środka RL8 i była ona porównywalna z procentowym wymyciem osadu przy użyciu wody, w przypadku której poziom usunięcia osadu wynosił 55,4\%. Usunięcie osadu z powierzchni rotora przedstawia fotografia 6 . Natomiast najskuteczniejsze usunięcie osadu uzyskano podczas użycia cieczy przemywającej na bazie środka RR21, gdy przy zastosowaniu roztworu 1-procentowego usunięcie osadu wynosiło prawie $76 \%$, co przedstawiono na fotografii 7 .

Należy zaznaczyć, że skuteczność usuwania osadu płuczkowego może być zróżnicowana w zależności od rodzaju płuczki użytej do wytwarzania osadu oraz jej parametrów. W związku z tym na rysunku 3 zestawiono procentowy wzrost usunięcia osadu płuczkowego w stosunku do wartości bazowej, którą było usunięcie osadu za pomocą wody. Na podstawie uzyskanych wartości stwierdzono maksymalny wzrost efektywności usuwania osadu równy $36,85 \%$ w stosunku do wartości bazowej. Takie usunięcie osadu otrzymano dla wspomnianego 1-procentowego roztworu cieczy przemywającej na bazie środka RR21.

Zaobserwowano również, że 1-procentowe stężenie użytych do badań środków pozwala na osiągnięcie wzrostu skuteczności usuwania na poziomie ok. 35\% do 37\% w porównaniu z wartością bazową. Natomiast zastosowanie roztworów 0,1-procentowych skutkuje większą rozbieżnością uzyskanych efektywności usuwania osadu, co przedstawia rysunek 3 .

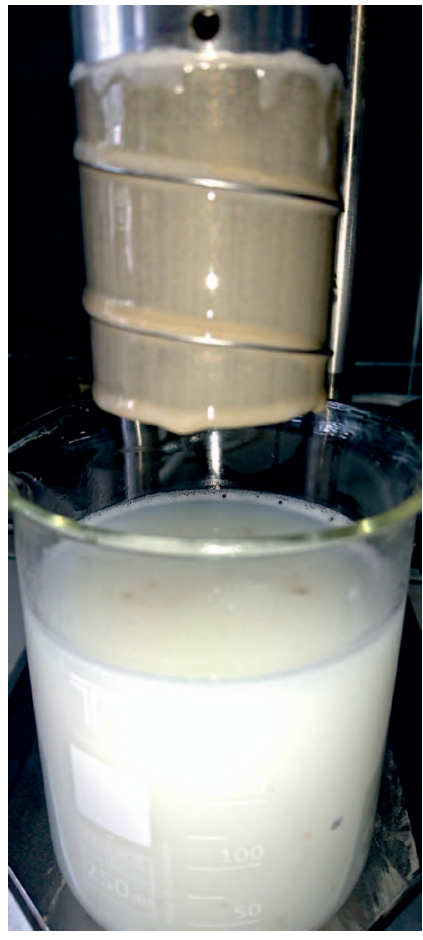

Fot. 6. Usunięcie osadu za pomocą cieczy przemywającej na bazie środka RL8, stężenie $0,1 \%$. Skuteczność usunięcia osadu równa $55,11 \%$

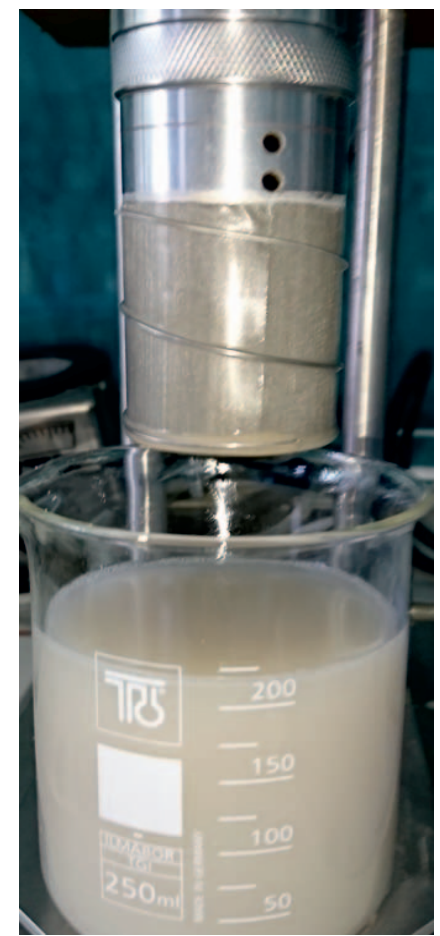

Fot. 7. Usunięcie osadu za pomocą cieczy przemywającej na bazie środka RR 21, stężenie 1,0\%. Skuteczność usunięcia osadu równa $75,84 \%$
Otrzymano od 8,53\% wzrostu usunięcia osadu (roztwór RR26) do ponad 29\% wzrostu usunięcia osadu (roztwór DC) w porównaniu $\mathrm{z}$ wartością bazową. Efekt usunięcia osadu płuczkowego z powierzeni rotora za pomocą 0,1 -procentowego roztworu cieczy DC przedstawiono na fotografii 8 . Z ekonomicznego punktu widzenia to właśnie te niższe wartości koncentracji mogą okazać się kluczowym parametrem przy wyborze środka do sporządzania cieczy przemywającej. 


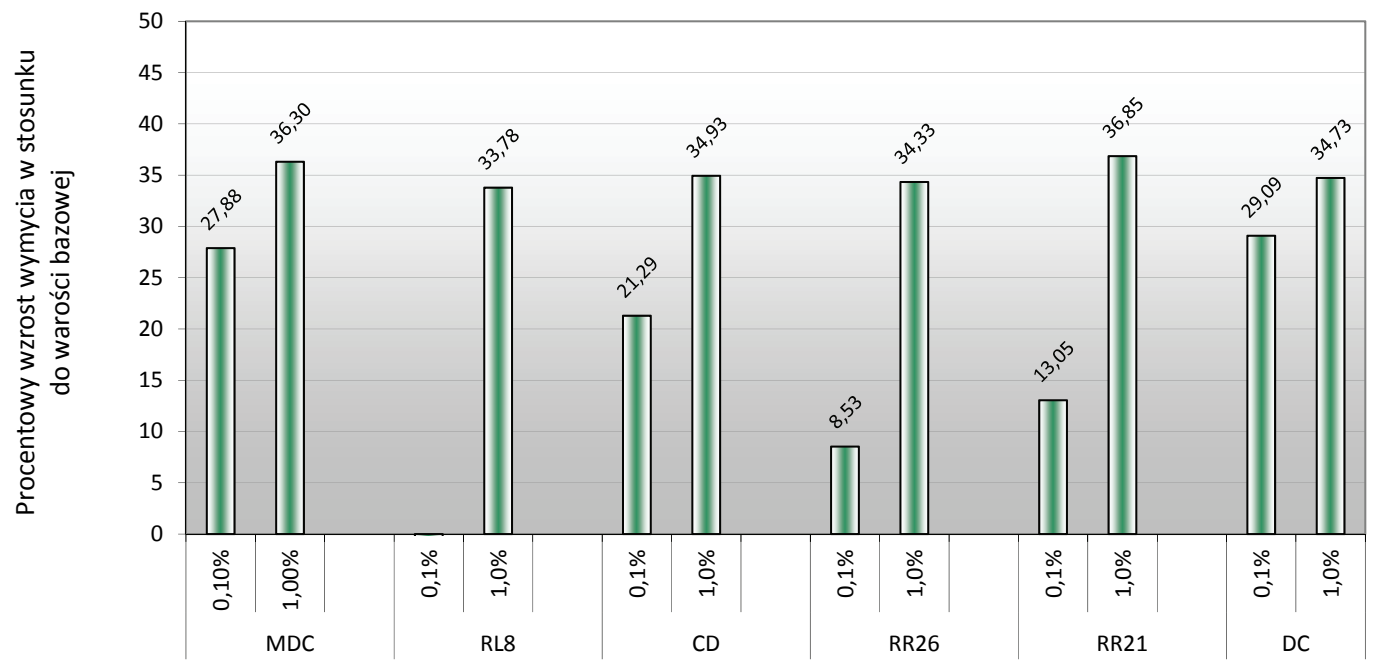

Stężenie [\%] i rodzaj użytego środka

Rys. 3. Zestawienie procentowego wzrostu usunięcia wytworzonego na powierzchni rotora osadu płuczkowego w stosunku do wartości bazowej

Konkludując, stwierdzono, że odpowiednio dobrana koncentracja cieczy przemywającej pozwala na uzyskanie oczekiwanego rezultatu, czyli wysokiej skuteczności usuwania osadu płuczkowego. Ustalono, że wzrost koncentracji środka chemicznego w opracowywanej cieczy przemywającej nie zawsze skutkuje proporcjonalnym wzrostem efektywności usuwania osadu. Niekiedy przy niskich stężeniach możliwe jest otrzymanie wysokiej skuteczności oczyszczania, natomiast wzrost stężenia może spowodować generowanie dodatkowych, nieuzasadnionych kosztów przy jednoczesnej niewielkiej poprawie skuteczności działania danej cieczy. Należy jednak mieć na uwadze, że efektywność usuwania powsta-

\section{Wnioski}

W trakcie realizacji badań oceny skuteczności oczyszczania kolumny rur okładzinowych przed cementowaniem przy użyciu wiskozymetru obrotowego wyciągnięto następujące wnioski:

- Badanie skuteczności działania cieczy przemywającej możliwe jest do przeprowadzenia przy użyciu wiskozymetru obrotowego, który jest podstawowym wyposażeniem laboratorium zaczynów cementowych.

- Należy uwzględniać i brać poprawkę na różnicę chropowatości powierzchni rotora w wiskozymetrze obrotowym i chropowatości powierzchni rur okładzinowych.

- Podczas prowadzonych badań uzyskano skuteczność usunięcia osadu na poziomie od 55,4\% przy zastosowaniu wody jako przemywki (punkt odniesienia) do wartości maksymalnej wynoszącej $75,84 \%$ podczas zastosowania 1-procentowego roztworu środka RR21.

- Procentowy wzrost usunięcia na powierzchni rotora osadu w porównaniu z wartością bazową wynosił od $8,5 \%$ dla łego w przestrzeni pierścieniowej osadu płuczkowego powinna być brana pod uwagę kompleksowo. Podczas opracowywania cieczy przemywającej należy uwzględnić zarówno kolumnę rur okładzinowych, jak i przewiercaną formację skalną, a także należy wziąć pod uwagę rodzaj i parametry stosowanej płuczki wiertniczej oraz szeroko pojęte warunki geologiczno-techniczne otworu.

Fot. 8. Usunięcie osadu za pomocą cieczy

przemywającej na bazie środka DC, stężenie $0,1 \%$.

Skuteczność usunięcia osadu równa $71,54 \%$, wzrost efektywności usuwania 29\% w porównaniu z wartością bazową

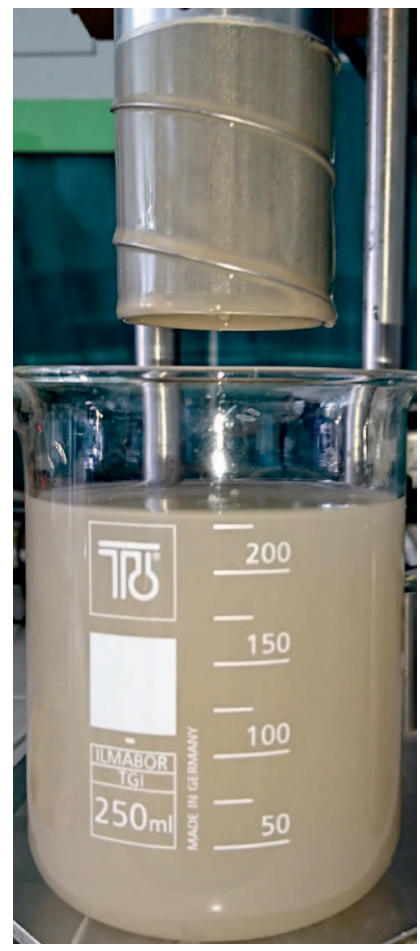

cieczy na bazie 0,1-procentowego środka RR26 do 36,85\% dla cieczy o koncentracji 1\% środka RR21.

- Użycie 1-procentowych koncentracji badanych środków do sporządzania cieczy przemywających skutkowało uzyskaniem porównywalnej, około 75-procentowej efektywności usuwania osadu, natomiast koncentracja środków równa $0,1 \%$ powodowała otrzymanie znacznie większej rozbieżności w efektywności usuwania osadu płuczkowego.

- Zauważyć należy, że efektywność usuwania osadu płuczkowego warunkowana jest nie tylko rodzajem zastosowanej cieczy przemywającej, ale głównie składem i parametrami użytej płuczki wiertniczej.

- Na podstawie analizy wyników uzyskanych z przeprowadzonych prac badawczych stwierdzono, że podczas badań skuteczności usuwania osadu płuczkowego przy użyciu wiskozymetru istotne jest określenie punktu odniesienia i porównywanie efektywności usuwania do tego właśnie punktu. 
Wydaje się oczywiste, że odpowiednie oczyszczanie przestrzeni pierścieniowej będzie możliwe do uzyskania dzięki odpowiedniemu doborowi składu i właściwości cieczy przemywającej i buforowej, a także zastosowaniu odpowiednich warunków tłoczenia i czasu kontaktu tych cieczy z powierzchnią rur okładzinowych oraz z formacją skalną. Jednakże należy również zaznaczyć, że odpowiednie uszczelnienie kolumny rur uzależnione jest nie tylko od prawidłowego oczyszczenia przestrzeni pierścieniowej. Na szczelność odwiertu wpływa również prawidłowo opracowany projekt i praktycznie przeprowadzony zabieg cementowania poszczególnych kolumn rur okładzinowych. Jednak prawidłowe oczyszczenie przestrzeni pierścieniowej przed zabiegiem cementowania jest jednym z elementów uzyskania skutecznego uszczelnienia otworu.

Prosimy cytować jako: Nafta-Gaz 2018, nr 9, s. 667-683, DOI: 10.18668/NG.2018.09.06

Artykuł nadesłano do Redakcji 4.07.2018 r. Zatwierdzono do druku 12.09.2018 r.

Artykuł powstał na podstawie pracy badawczej pt. Analiza możliwości poprawy oczyszczenia przestrzeni pierścieniowej otworu wiertniczego przed zabiegiem cementowania - praca INiG - PIB na zlecenie MNiSW; nr zlecenia: 58/KW/17, nr archiwalny: DK-4100/58/17.

\section{Literatura}

[1] Błaż S.: Nowe rodzaje cieczy przemywających osady z płuczki inwersyjnej przed zabiegiem cementowania otworów wiertniczych. Nafta-Gaz 2017, nr 5, s. 302-311, DOI: 10.18668/ NG.2017.05.02.

[2] Ciechanowska M. i in.: Ekshalacje gazu ziemnego - polskoukrainski problem przedgórza Karpat; Analiza i ocena zagrożeń ekshalacjami gazu. Kraków 2008.

[3] Gunawan S., Fowler D., Mack A.: High-Performance Wellbore Displacement Spacer System. AADE-17-NTCE-067, 2017.

[4] Habrat S., Raczkowski J., Zawada S.: Technika i technologia cementowań w wiertnictwie. Wydawnictwo Geologiczne, Warszawa 1980.

[5] Jasiński B.: Ocena wplywu cieczy przemywajacej na jakość zacementowania rur $w$ otworze wiertniczym po użyciu płuczki glikolowo-potasowej. Nafta-Gaz 2016, nr 6, s. 413-421, DOI: 10.18668/NG.2016.06.04.

[6] Kremieniewski M.: Ograniczenie ekshalacji gazu w otworach wiertniczych poprzez modyfikacje receptur oraz ksztattowanie się struktury stwardniałych zaczynów uszczelniajacych. Prace INiG - PIB nr 199, Kraków 2016.

[7] Kremieniewski M., Kędzierski M., Rzepka M.: Symulator przepływu cieczy wiertniczych - zasada pomiaru i możliwości badawcze. Nafta-Gaz 2018, nr 7, s. 518-525, DOI: 10.18668/ NG.2018.07.05.

[8] Kremieniewski M., Rzepka M.: Celowość prowadzenia prac badawczych nad nowymi środkami obniżajacymi filtrację zaczynów cementowych. Nafta-Gaz 2017, nr 8, s. 583-590, DOI: 10.18668/NG.2017.08.05.

[9] Kremieniewski M., Rzepka M.: Hybrydowa ciecz przemywajaca do oczyszczania przestrzeni pierścieniowej otworu wiertniczego. Nafta-Gaz 2018, nr 5, s. 372-379, DOI: 10.18668/ NG.2018.05.04.

[10] Kremieniewski M., Rzepka M.: Poprawa szczelności płaszcza cementowego za pomoca innowacyjnych dodatków antymigracyjnych. Nafta-Gaz 2018, nr 6, s. 457-464, DOI: 10.18668/ NG.2018.06.06.

[11] Kremieniewski M., Rzepka M.: Przyczyny i skutki przeptywu gazu w zacementowanej przestrzeni pierścieniowej otworu wiertniczego oraz metody zapobiegania temu zjawisku. Nafta-Gaz 2016, nr 9, s. 722-728, DOI: 10.18668/NG.2016.09.06.

[12] Kremieniewski M., Rzepka M., Kędzierski M.: Wpływ czasu kontaktu cieczy przemywajacej z osadem płuczkowym na skuteczność oczyszczania przestrzeni pierścieniowej. Nafta-Gaz 2018, nr 1, s. 29-36, DOI: 10.18668/NG.2018.01.03.

[13] Lavrov A., Torsaeter M.: Physics and Mechanics of Primary Well Cementing. Springer, 2016.

[14] Li L. i in.: A Novel Spacer System to Prevent Lost Circulation in Cementing Applications. AADE-16-FTCE-13, 2016 AADE Fluids Technical Conference and Exhibition, Houston, Texas, April 12-13, 2016.

[15] Li L. i in.: Evaluation of a New Spacer System Mixed On-TheFly. AADE-16-FTCE-51, 2016 AADE Fluids Technical Conference and Exhibition, Houston, Texas, April 12-2016.

[16] Martin M., Latil M., Vetter P.: Mud Displacement by Slurry During Primary Cementing Jobs - Predicting Optimum Conditions, SPE-7590-MS, SPE Annual Fall Technical Conference and Exhibition, 1-3 October, Houston, Texas, 1978.

[17] Nelson E.B. i in.: Well Cementing. Schlumberger Educational Service, Houston, Texas, USA, 1990.

[18] Sauer C.W.: Mud Displacement During Cementing: A State of the Art. JPT 1987, vol. 39, no. 9, DOI: 10.2118/14197-PA.

[19] Shadravan A., Tarrahi M.: Agile Data-Driven Fluid Design: Predicting the Properties of Drilling, Spacer and Cement Slurry Fluids. AADE-16-FTCE-07, 2016 AADE Fluids Technical Conference and Exhibition, Houston, Texas, April 12-13, 2016.

[20] Stryczek S. i in.: Studia nad doborem zaczynów uszczelniajacych $w$ warunkach wierceń $w$ basenie pomorskim. Wydawnictwo AGH, Kraków 2016.

[21] Stryczek S., Gonet A.: Kierunki ograniczania migracji gazu z przestrzeni pierścieniowej otworu wiertniczego. WUG 2005, nr 3, s. 10-13.

[22] Uliasz M., Chudoba J., Herman Z.: Pluczki wiertnicze z inhibitorami polimerowymi i ich oddziatywanie na przewiercane skaty. Prace INiG 2006, nr 139, s. 72-82.

[23] Uliasz M., Zima G., Błaż S., Jasiński B.: Systemy płuczek wiertniczych do wiercenia otworów w formacjach tupkowych. W: Raczkowski J. (red.), Rzeczpospolita tupkowa, INiG, Kraków 2012, s. 225-241.

[24] Uliasz M. i in.: Ocena wptywu cieczy wiertniczych w aspekcie zapobiegania migracji gazu w otworach na przedgórzu Karpat. Nafta-Gaz 2015, nr 1, s. 11-17.

[25] Zima G.: Wpływ właściwości pluczek wiertniczych na jakość cementowania $w$ gazonośnych poziomach miocenu. Nafta-Gaz 2014, nr 12, s. 899-907.

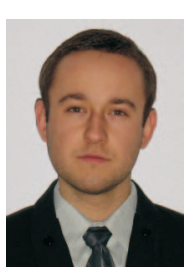

Dr inż. Marcin KREMIENIEWSKI

Adiunkt w Zakładzie Technologii Wiercenia.

Instytut Nafty i Gazu - Państwowy Instytut Badawczy ul. Lubicz 25 A

31-503 Kraków

E-mail: marcin.kremieniewski@inig.pl 